\title{
Voimasuhteet ruokamarkkinoilla - Bruttomarginaalien muodostuminen ja kehitys Suomen elintarvikeketjussa
}

\author{
Kyösti Arovuori ${ }^{1)}$, Hanna Karikallio ${ }^{1)}$ ja Perttu Pyykkönen ${ }^{1)}$ \\ ${ }^{1)}$ Pellervon taloustutkimus PTT, Eerikinkatu 28A, 01510 Helsinki \\ kyosti.arovuori@ptt.fi,hanna.karikallio@ptt.fi ja perttu.pyykkonen@ptt.fi
}

Tiivistelmä: Tutkimuksessa analysoidaan suomalaisen elintarvikeketjun rakenteen ja voimasuhteiden kehitystä. Analyysi tehdään jaottelemalla elintarvikkeisiin käytetyt kokonaiskulutusmenot elintarvikeketjun eri osapuolille. Osuudet elintarkkeiden kokonaiskulutusmenoista esitetään erikseen maataloudelle, kotimaiselle elintarviketeollisuudelle, tuonnille sekä kaupalle ja ravintoloille. Lisäksi kehitystä vertaillaan yhdeksän eri maan välillä. Tulosten perusteella kauppa ja ravintolat ovat kasvattaneet omaa osuuttaan ruokaketjussa vuosina 2000-2009. Lisäksi tuonnin merkitys on ollut voimakkaassa kasvussa. Kotimainen maatalous ja elintarviketeollisuus ovat vastaavasti menettäneet asemiaan. Tutkimuksen kansainvälisen vertailun mukaan kehitys on ollut samansuuntaista myös muualla. Maatalous on menettänyt osuuttaan ruokaan käytetyistä kokonaismenoista lähes kaikissa vertailussa mukana olleissa maissa. Elintarviketeollisuuden osuus on laskenut tai pysynyt ennallaan. Tuonnin merkityksen kasvu näkyy selvästi kaikissa vertailumaissa.

Asiasanat: Bruttomarginaali, elintarvikeketju, elintarvikkeiden hinnanmuodostus. 


\section{Johdanto}

Nopeat muutokset kansainvälisillä maataloushyödyke- ja elintarvikemarkkinoilla ovat entistäkin voimakkaammin nostaneet esiin kysymyksen elintarvikkeiden hinnanmuodostuksesta ja hintamarginaaleista. Kuka hyötyy ja kuka häviää kasvaneesta hintojen vaihtelusta elintarvikemarkkinoilla? Kuinka hintamuutokset jakautuvat elintarvikeketjun sisällä?

Elintarvikkeiden hintamarginaalilla tarkoitetaan elintarviketeollisuuden, kaupan ja muiden väliportaiden osuutta elintarvikkeen kuluttajahinnasta. Kasvaneesta hintamarginaalista on raportoitu monissa empiirisissä sekä kotimaisissa että ulkomaisissa tutkimuksissa (esim. Digby, 1989; Kinsey ja Senauer, 1996; Løyland et al., 2001; Aalto-Setälä, 2002; Kuosmanen et al., 2009; Kotilainen et al., 2010).

Yksi merkittävimmistä elintarvikkeiden hinnanmuodostusta ohjaavista tekijöistä on kotimarkkinoiden kilpailu. Yleinen näkemys on, että vähittäis- ja tukkukaupan markkinavoima elintarvikeketjussa on kasvanut, mikä on johtanut kaupan osuuden kasvuun elintarvikkeiden kuluttajahinnoista (McCorriston, 2002; Schroeter et al., 2000). Epätäydellisen kilpailun lisäksi muita syitä kasvaneille elintarvikkeiden hintamarginaaleille ovat erot tuottavuuden kasvussa eri sektoreilla, maatalouspolitiikka, kansainvälisen kaupan vapautuminen sekä kuluttajien ostokäyttäytymisen muutos, mikä näkyy valmisruokien ja puolivalmisteiden kulutuksen kasvuna (ts. tuotteiden jalostusasteen nousuna).

Kaikki nämä tekijät nousevat esiin myös tarkasteltaessa Suomen elintarvikemarkkinoita. Kauppa on voimakkaasti keskittynyttä: neljän suurimman vähittäiskaupparyhmän markkinaosuus on kasvanut yli 95 prosenttiin. Lisäksi tukkukaupassa kolme suurinta yritystä pitää halussaan noin $80 \%$ alan liikevaihdosta. Suuret kaupparyhmät ovat hankkineet markkinavoimaa myös logistisilla järjestelyillä sekä hyödyntämällä kansainvälisiä osto-organisaatioita ja kaupan omia tuotemerkkejä. Tämän seurauksena kaupan neuvotteluasema elintarvikeketjussa on vahvistunut. Aseman vahvistuminen on entisestään parantanut mahdollisuuksia käyttää hyväksi ostajan voimakasta asemaa suhteessa elintarviketeollisuuteen (Jalonoja ja Pietola, 2004). Markkina- ja neuvotteluvoima ovat markkinaprosessille tunnusomaisia monitahoisia ilmiöitä, joilla voi olla merkittäviä vaikutuksia niin tuotanto- ja jakeluportaille kuin kuluttajillekin. Näiden ilmiöiden merkityksestä suomalaisessa elintarvikeketjussa tarvitaan kuitenkin enemmän tutkimustietoa.

Myös Euroopan komissio on kiinnittänyt erityistä huomiota elintarvikeketjun toimivuuteen Euroopassa. Komissio on jäsentänyt elintarvikeketjuun kohdistuvia haasteita sekä tarvittavia toimenpiteitä. Komissio pitää tärkeänä elintarvikeketjun kilpailukyvyn ylläpitämistä EU:n jäsenvaltioissa. Elintarvikeketjun painopisteeksi on määritetty kestävien ja markkinaehtoisten suhteiden muodostaminen eri toimijoiden välille. Komissio on huolestunut elintarvikeketjun toimijoiden epätasaisista neuvotteluvoimista sekä hyvän kauppatavan vastaisten käytäntöjen ilmenemisestä elintarvikemarkkinoilla. Lisäksi komissio korostaa koko arvoketjun läpinäkyvyyden lisäämistä kilpailun edistämiseksi ja hintavaihtelujen sietokyvyn parantamiseksi. (Euroopan komissio, 2009.)

Tässä tutkimuksessa analysoimme marginaaleja elintarvikeketjun bruttoarvon muodostumisesta Suomessa. Analyysi perustuu ruokaan käytettävien kokonaiskulutusmenojen jakamiseen elintarvikeketjun eri osille: maatalouteen, elintarviketeollisuuteen, tuontiin, veroihin sekä kauppaan ja ravintolapalveluihin. Tavoitteena on analysoida elintarvikkeiden hinnanmuodostusta ja sen kehitystä vuosina 2000-2009. Bruttomarginaaleja tarkastellaan myös erikseen tuoteryhmittäin liha-, maito- ja viljatuotteille. Tämän lisäksi tehdään maiden välistä vertailua yksinkertaistetummalla laskentatavalla. Elintarvikkeiden bruttomarginaalien muodostumista Suomessa verrataan Espanjan, Italian, IsoBritannian, Ranskan, Ruotsin, Saksan, Tanskan, ja USA:n vastaaviin bruttomarginaalilukuihin. Bruttomarginaalien kehitys eri maissa heijastaa sekä kansallisia piirteitä elintarvikkeiden hinnanmuodostuksen dynamiikassa että myös kilpailullisuuden muutoksia kunkin maan elintarvikemarkkinoilla. 


\section{Aineisto ja menetelmät}

Seuraavissa luvuissa laskemme elintarvikeketjun eri sektorien bruttomarginaaleja hyödyntämällä elintarvikkeiden kulutuksen, tuotannon ja ulkomaankaupan bruttomääräisiä tilastoarvoja. Lähestymistapamme elintarvikkeiden hinnanmuodostukseen perustuu toisin sanoen kotimaisten elintarvikkeiden, alkoholittomien juomien ja ravintolapalveluiden kokonaiskulutusmenojen jakamiseen elintarvikeketjun merkittävimmille sektoreille: maatalouteen, teollisuuteen sekä kauppaan ja ravintolapalveluihin. Koska kiinnostuksen kohteena on kotimainen elintarvikeketju, tuonti on erotettu yhdeksi elintarvikeketjun erilliseksi osaksi. Vastaavasti maatalouden ja elintarviketeollisuuden vienti sekä vientielintarvikkeiden valmistukseen käytetty kotimaisen maatalousraaka-aineen arvo on vähennetty maatalouden ja elintarviketeollisuuden osuuksista. Lisäksi hinnanmuodostuksessa on yhtenä osana huomioitu elintarvikkeiden, alkoholittomien juomien ja ravintolapalveluiden arvonlisäverot sekä virvoitusjuomavero.

Laskelmien perustana on usean suomalaisen organisaation suorittama kattava tilastointi. Kulutusta ja teollisuuden tuotantoa koskevat luvut on poimittu Tilastokeskuksen tietokannoista. Ulkomaankauppaluvut ovat peräisin Tullin ylläpitämästä Uljas-tietokannasta sekä Elintarviketeollisuusliiton (ETL) vienti- ja tuontitilastoista, joissa maataloushyödykkeiden ja elintarvikkeiden ulkomaankauppa on selkeästi eroteltu. Tullin Uljas-tietokannasta saadaan myös elintarviketeollisuuden elintarviketuonti, jolloin elintarvikkeiden kokonaistuonti pystytään jakamaan teollisuuden sekä kaupan ja ravintolapalveluiden kesken. Maatalouden tuotannon bruttoarvot on kerätty Maa- ja elintarviketalouden tutkimuskeskuksen (MTT) vuosittain julkaisemasta maataloustuotannon kokonaislaskelmasta.

Tarkastelusta on irrotettu alkoholin ja eläinten ruokien valmistus ja myynti sekä valmistukseen tarvittava maatalousraaka-aineen käyttö. Panimoteollisuuden ja alkoholijuomien valmistuksessa käytettävän maatalousraaka-aineen bruttoarvo sekä myös rehuteollisuuteen menevä maataloustuotannon bruttoarvo on jouduttu arviomaan maataloustuotantoerien bruttoarvojen perusteella. Muilta osin panimoteollisuudesta sekä alkoholijuomien valmistuksesta samoin kuin rehujen valmistuksesta on saatavissa omat toimialakohtaiset tilastot. Ravintolapalveluiden kulutusmenojen jakaminen ruokaan ja alkoholiin onnistuu melko tarkasti Majoitus- ja ravintolapalvelut Ry:n (MaRa Ry) kattavan tilastoinnin avulla.

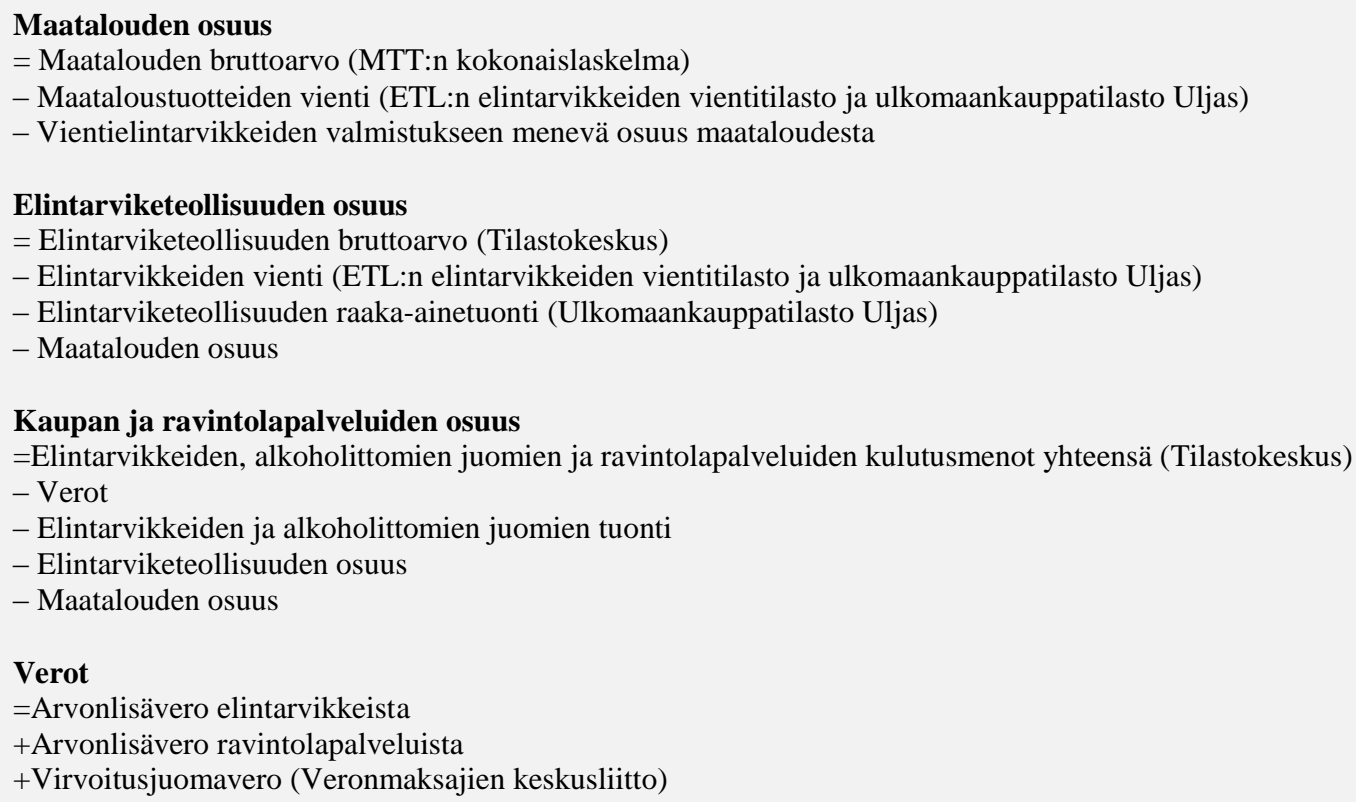

Kaupan ja ravintolapalveluiden osuus

=Elintarvikkeiden, alkoholittomien juomien ja ravintolapalveluiden kulutusmenot yhteensä (Tilastokeskus)

- Verot

- Elintarvikkeiden ja alkoholittomien juomien tuonti

- Elintarviketeollisuuden osuus

- Maatalouden osuus

Verot

=Arvonlisävero elintarvikkeista

+Arvonlisävero ravintolapalveluista

+Virvoitusjuomavero (Veronmaksajien keskusliitto)

Elintarvikkeiden ja alkoholittomien juomien tuonti (ETL:n elintarvikkeiden vientitilasto ja ulkomaankauppatilasto Uljas) $=$ Elintarviketeollisuuden tuonti (Ulkomaankauppatilasto Uljas)

+Tuonti kauppaan 
Ylläkuvatulla tavalla laskettu arvio elintarvikeketjun bruttoarvon muodostumisesta vuonna 2009 on esitetty kuviossa 1. Laatikkojen koot kuviossa 1 ovat verrannollisia ja ne vastaavat sektorien euromääräisiä bruttoarvoja.

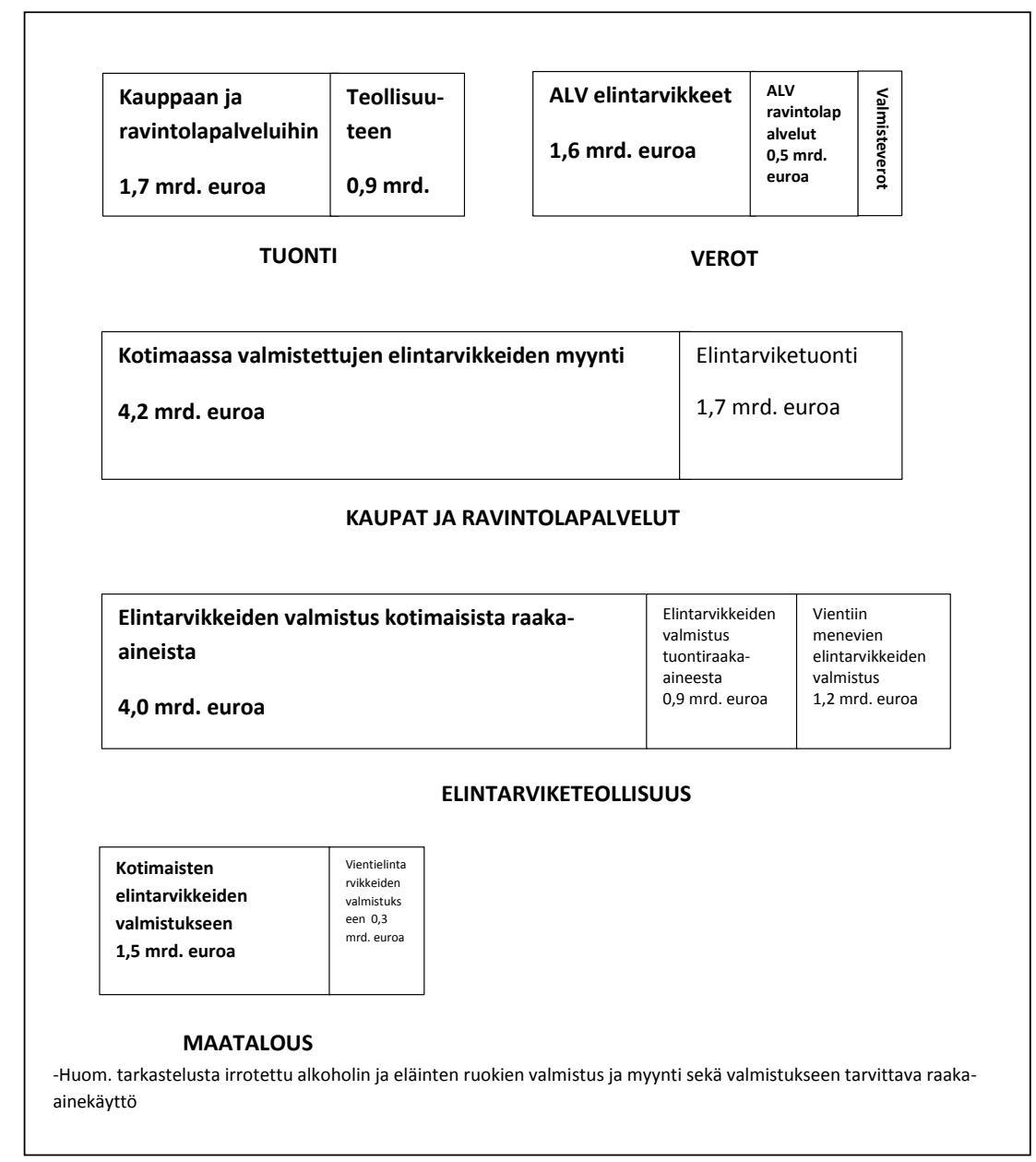

Kuvio 1. Elintarvikeketjun bruttoarvon (14,4 mrd. €) muodostuminen vuonna 2009

\section{Tulokset ja tulosten tarkastelu}

\section{Kotimaisen elintarvikeketjun bruttomarginaalit vuosina 2000-2009}

Kuviossa 2 on esitetty elintarvikeketjun eri osien - maatalouden, elintarviketeollisuuden, kaupan ja ravintolapalveluiden, tuonnin sekä verojen - bruttomarginaalit, eli suhteelliset osuudet elintarvikeketjun bruttoarvosta vuosina 2000-2009. ${ }^{1}$

Kuviossa 2 esitettyjen tulosten perusteella suomalaisen maatalousraaka-aineen osuus elintarvikeketjun hinnanmuodostuksessa on pienentynyt 2000-luvulla: maatalouden osuus elintarvikkeiden bruttoarvosta oli vuonna 2009 keskimäärin hieman yli $10 \%$. Vuodesta 2000 kotimaisen maatalouden bruttomarginaali on pudonnut 4 prosenttiyksikköä.

Tulosten perusteella maatalouden merkitys elintarvikeketjussa on pienentynyt. Kehitystä taustoittavat tekijät. Maatalouden tukitoimenpiteissä on siirrytty tuotantoon sidotuista tuista yhä enemmän suoriin tukiin. Jalostetumpien tuotteiden kulutusosuuden kasvu merkitsee

\footnotetext{
${ }^{1}$ Tarkemmat tiedot kuvion laskelmista pyydettäessä kirjoittajilta.
} 


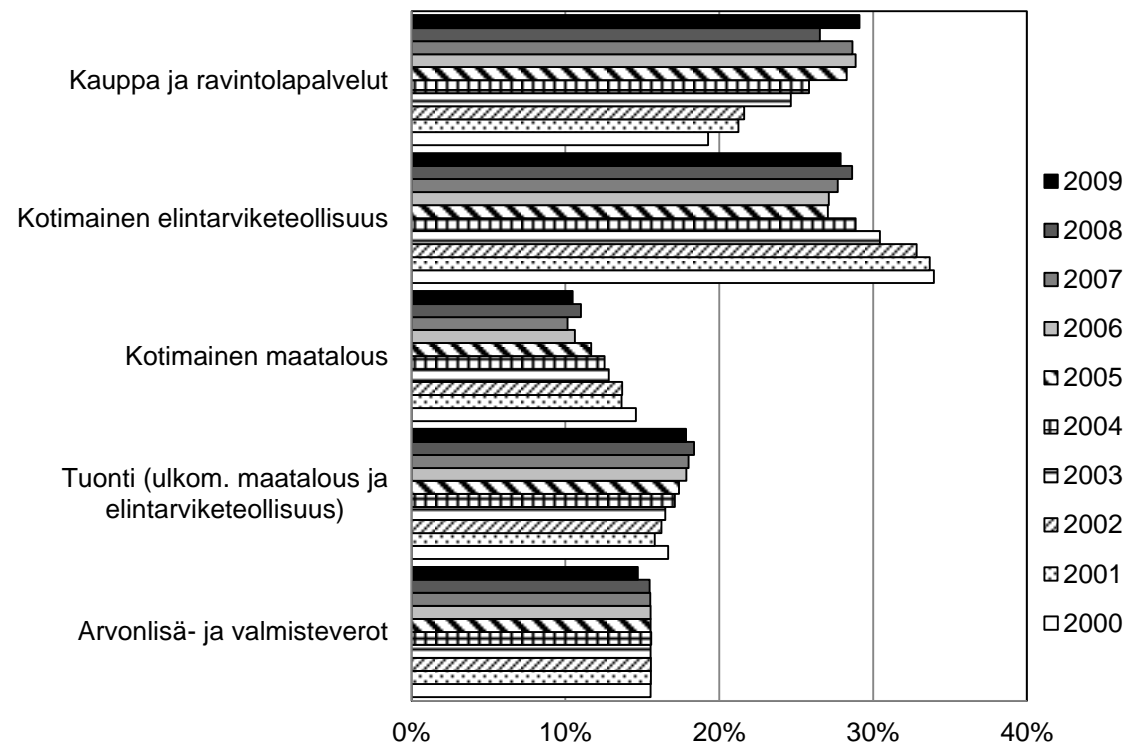

Kuvio 2. Elintarvikeketjun bruttomarginaalit 2000-2009. Lähteet: Tilastokeskus, Tulli, MTT taloustutkimus, Elintarviketeollisuusliitto, MaRa ry ja kirjoittajien omat laskelmat

suoraan sitä, että ruuan hinnasta yhä suurempi osuus perustuu muuhun kuin maataloudesta tulevaan raaka-aineeseen. Samalla tavalla kotimaisen maatalouden osuuteen ruuan kokonaiskulutusmenoista vaikuttaa ravintolaruokailun kasvu sekä toisaalta myös tuonnin kasvu. Tuottavuuden kasvu maataloudessa on ollut nopeampaa kuin elintarviketeollisuudessa ja kaupassa, mikä sekin osaltaan pienentää maatalouden osuutta ruuan hinnassa.

Kotimaisen elintarviketeollisuuden osuus elintarvikkeiden kokonaiskulutusmenoista on kuvion 2 mukaan pudonnut 2000-luvulla keskimäärin alle kolmannekseen. Elintarviketeollisuuden osuus elintarvikeketjun bruttoarvosta oli vuonna 2000 keskimäärin noin $34 \%$. Vuonna 2009 kyseinen osuus oli vastaavasti noin $28 \%$. Elintarviketeollisuuden bruttomarginaalin huomattava lasku on toisaalta yllättävä, koska samaan aikaan elintarvikkeiden jalostusaste on noussut. Voidaankin todeta, että tulosten perusteella elintarviketeollisuuden asema kotimaan elintarvikemarkkinoilla on ollut haastava; elintarviketeollisuus ei ole saanut nostettua omia hintojaan, vaan se on joutunut pärjäämään ensisijaisesti tuottavuuden kasvulla. On kuitenkin hyvä huomioida, että elintarviketeollisuuden tuottavuus ei ole kasvanut yhtä nopeasti kuin esimerkiksi vähittäiskaupan tuottavuus (Huovari ja Jalava, 2007).

Suomen EU-jäsenyys moninkertaisti elintarvikkeiden tuonnin. Kotimarkkinoiden integroituessa kansainvälisiin markkinoihin elintarviketeollisuus kilpailee tiiviisti ulkomaisten tavarantoimittajien kanssa vähittäismyyntimarkkinoilla. Vuonna 2009 tuontituotteiden osuus suomalaisten elintarvikkeisiin käyttämistä kokonaiskulutusmenoista oli noin $19 \%$. Tuontituotteiden osuus elintarvikeketjun bruttoarvosta on 2000-luvulla kasvanut tasaisesti yhteensä noin 2 prosenttiyksiköllä.

Kuviossa 2 esitettyjen laskelmien perusteella kaupan ja ravintoloiden osuus ruuan kulutusmenoista on kasvanut selvästi 2000-luvulla. Kaupan ja ravintoloiden bruttomarginaali oli vuonna 2009 jo keskimäärin yli $29 \%$. Marginaali on kasvanut 10 prosenttiyksikköä vuodesta 2000. Kaupan ja ravintolapalveluiden bruttomarginaali ylittää siis elintarviketeollisuuden bruttomarginaalin. Osa kaupan ja ravintolapalveluiden osuuden kasvusta selittyy sillä, että ravintolasyöminen on kasvanut jonkin verran kotona syömistä nopeammin. Ravintolapalveluihin käytettävät kulutusmenot (ilman alkoholia) ovat kasvaneet vuodesta 2000 vuoteen 2009 noin $50 \%$ ja muut ruokamenot noin $40 \%$. Ravintolasyömisen osuus on kuitenkin vain noin $20 \%$ kaikista kuluttajien ruokamenoista, joten myös kauppa on kasvattanut osuuttaan ruokaan käytettävistä kulutusmenoista.

Integroituvien markkinoiden kilpailupaine ei ole ulottunut kaupan vähittäismyyntiportaaseen samassa määrin kuin maatalouteen ja teollisuuteen. Kuviossa 2 esitetyt tulokset tukevat monissa tutkimuksissa esitettyä johtopäätöstä: vähittäiskaupan neuvotteluasema elintarvikeketjussa on vahvistunut suhteessa kotimaiseen maatalouteen ja elintarviketeollisuuteen. 
Monesti nostetaan esiin näkemys, jonka mukaan yksi kaupan bruttomarginaalia kasvattava tekijä on toimintojen siirtyminen muilta sektoreilta kaupan hoidettavaksi. Erityisesti kuljetuksia on siirtynyt elintarviketeollisuudelta kaupalle. Kun energian hinnat ovat olleet nousussa ja kuljetusmatkat ovat pidentyneet tuotannon keskittymisen myötä, kustannustekijät saattavat olla yksi selittävä tekijä kaupan kasvaneelle bruttomarginaalille.

Tarkasteltaessa kuviossa 2 esitettyjä bruttomarginaaleja havaitaan, että vuoteen 2005 saakka bruttomarginaalien kehityksellä oli selkeä suunta: kaupan ja ravintoloiden bruttomarginaali kasvoi maatalouden ja elintarviketeollisuuden bruttomarginaalien pienentyessä vastaavasti. Vuodesta 2005 eteenpäin bruttomarginaalien kehitys eri sektorin välillä on ollut huomattavasti tasaisempaa. Vuosi 2008 on tässä kehitystarkastelussa erityisen mielenkiintoinen, sillä silloin maatalous ja elintarviketeollisuus pystyivät kasvattamaan bruttomarginaalejaan kaupan ja ravintolapalveluiden bruttomarginaalin kustannuksella. Kuten edellä on selvitetty, kyseisenä vuonna sekä monista kysyntäettä tarjontatekijöistä johtuen maatalouden ja elintarviketeollisuuden neuvotteluvoima elintarvikeketjussa parani.

\section{Elintarvikeketjun bruttomarginaalit tuoteryhmittäin}

Kuviossa 3 on esitetty arvio ruokaan käytettävien kulutusmenojen jakautumisesta elintarvikeketjun eri sektoreille liha-, maito- ja viljatuoteryhmissä Suomessa vuonna 2009.

Kotimaisen maatalouden osuus ruuan kulutusmenoista vaihtelee huomattavasti tuoteryhmittäin. Vuoden 2009 lukujen mukaan maidontuottaja sai maitotaloustuotteiden kulutusmenoista keskimäärin noin $30 \%$, lihantuottaja lihatuotteiden kulutusmenoista noin $20 \%$ ja viljantuottaja viljatuotteiden kulutusmenoista noin $6,5 \%$. Näiden lukujen perusteella täydellisen kilpailun markkinoilla 10 prosentin tuottajahinnan nousu välittyy suoraan kuluttajahintoihin ja nostaa maitotaloustuotteiden keskimääräistä kuluttajahintaa $3 \%$, lihatuotteiden $2 \%$ ja viljatuotteiden $0,65 \%$.

Vaikka suuretkaan tuottajahintojen muutokset eivät ruuan hintaa kovin paljon heiluta, kilpailullisilla elintarvikemarkkinoilla tuottajahintojen kansainvälisestä kehityksestä on kansallisella tasolla vaikea poiketa. Erityisen selvästi tämä on nähtävissä voimakkaasti integroituneilla lihamarkkinoilla. Hinnassa voi olla maiden välillä perusteltuja tasoeroja ja hintakehityksessä viiveitä, kuten on Suomen maitomarkkinoilla suhteessa EU:n maitomarkkinoihin. Pidemmällä aikavälillä tuonti tai tuonnin uhka kuitenkin integroi hintakehityksen. Itse asiassa juuri maitomarkkinoilla vuoden 2008 poikkeuksellisen suuri tuottajahinnan nousu Suomessa ja vuoden 2009 tuottajahinnan alentaminen ovat hyvä esimerkki integroituneiden markkinoiden paineesta.

Myös kotimaisen elintarviketeollisuuden osuus ruuan kulutusmenoista vaihtelee huomattavasti tuoteryhmittäin. Suurin osuus teollisuudella on viljatuotteissa, joissa mylly- ja leipomoteollisuuden osuus viljatuotteiden kulutusmenoista oli vuonna 2009 noin $42 \%$. Myös lihasektorilla teollisuus saa lihatuotteiden kulutusmenoista yli $40 \%$. Lihateollisuuden osalta on kuitenkin huomattava, että luku sisältää myös pitkälle jalostettujen einesten valmistuksen. Lihateollisuuteen laskettava einesten valmistus käyttää raaka-aineena myös esimerkiksi vihanneksia ja viljatuotteita, joiden osuutta ei ole pystytty vähentämään teollisuuden raaka-ainehankintamenoista. Näin ollen teollisuuden osuus tulee lihatuotteissa yliarvioitua. Meijeriteollisuuden saama osuus on tarkastelluista elintarviketeollisuuden aloista pienin, noin $19 \%$. Tämä selittyy pitkälti sillä, että nestemäisen maidon osuus maitotaloustuotteiden kulutusmenoista on suuri, mutta sen jalostusaste on suhteellisen alhainen. 


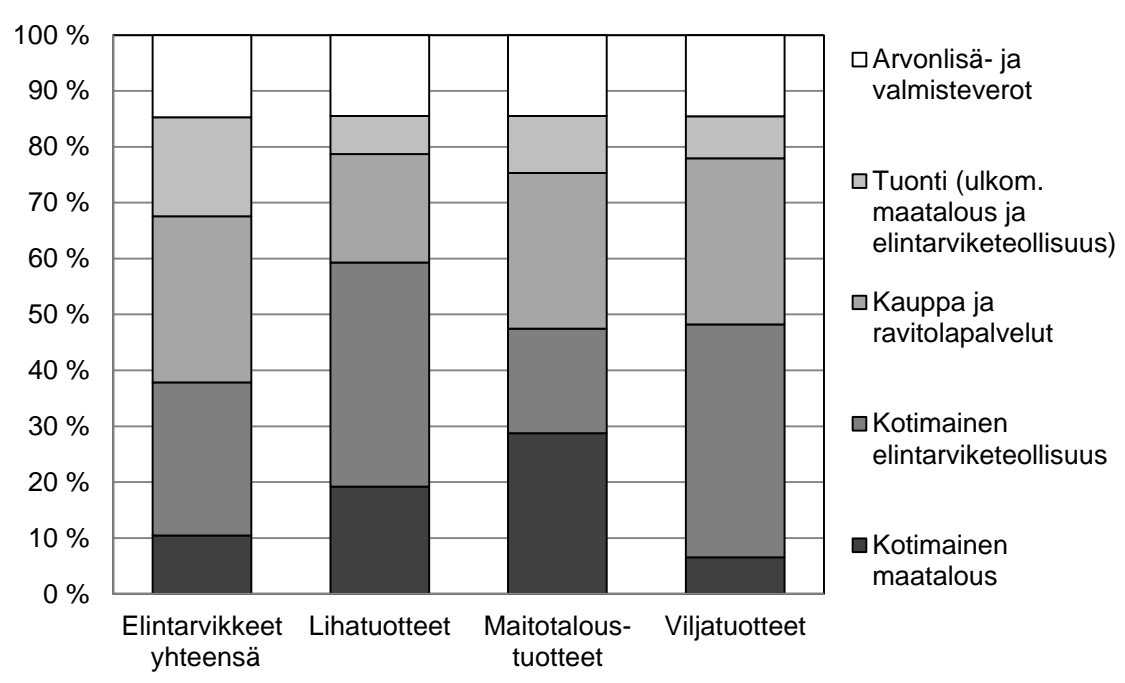

Kuvio 3. Elintarvikeketjun bruttomarginaalit tuoteryhmittäin vuonna 2009. Lähteet: Tilastokeskus, Tulli, MTT taloustutkimus, Elintarviketeollisuusliitto, MaRa ry ja kirjoittajien omat laskelmat.

Kuviosta 3 nähdään lisäksi, että kaupan ja ravintoloiden osuus ruuan kulutusmenoista tuoteryhmätasolla on 20-30\%. Kaupan rooli on tuoteryhmästä riippumatta tasaisen vahva.

Kuviossa 4 on esitetty tuoteryhmätasolla elintarvikeketjun eri sektorien bruttomarginaalien muutokset vuodesta 2000 vuoteen 2009. Vastaavasti kuviossa 5 on esitetty keskimääräiset prosentuaaliset bruttomarginaalien vuosimuutokset vuosilta 2000-2009.

Kuvioista nähdään, että maidontuottajien osuus maitotuotteiden kulutuksen bruttoarvosta on pudonnut verrattain paljon: vuodesta 2000 vuoteen 2009 maidontuottajien bruttomarginaali on pienentynyt 12,6 prosenttiyksikköä, keskimäärin 3,8 \% vuodessa. Lihantuottajien osuus lihatuotteiden kokonaiskulutusmenoista on vastaavasti pudonnut noin 4 prosenttiyksikköä. Tämä on tarkoittanut noin 2 prosentin keskimääräistä vuotuista pudotusta 2000-luvulla. Viljelijöiden osuus viljatuotteiden kulutuksen bruttoarvosta on tulosten mukaan sen sijaan noussut: vuosina 2000-2009 viljelijöiden bruttomarginaali on kasvanut yhteensä 1,7 prosenttiyksikköä eli keskimäärin $0,4 \%$ vuodessa. Tulos selittyy paljolti viljan hinnan merkittävällä nousulla vuonna 2007.

Teollisuuden bruttomarginaalit ovat pienentyneet elintarvikkeiden hinnanmuodostuksessa maitotaloustuotteita lukuun ottamatta muissa tarkasteltavissa tuoteryhmissä selvästi vuosina 20002009. Viljatuotteissa mylly- ja leipomoteollisuuden bruttomarginaali on alentunut keskimääräistä enemmän: vuosien 2000 ja 2009 välillä lihateollisuuden bruttomarginaali on laskenut yhteensä 9,5 prosenttiyksikköä, mikä on vastannut yli 3 prosentin keskimääräistä vuotuista alenemista. Lihatuotteissa teollisuuden bruttomarginaali on pienentynyt vuosina 2000-2009 liki 7,8 prosenttiyksikköä. Keskimäärin teollisuuden osuus lihatuotteiden bruttoarvosta on siis pienentynyt $2,5 \%$ vuodessa. Meijeriteollisuus on sen sijaan pystynyt kasvattamaan bruttomarginaaliaan tarkasteltavalla aikavälillä 2,5 prosenttiyksiköllä. Tämä on tarkoittanut 0,4 prosentin keskimääräistä vuotuista kasvua. Suomessa maitotaloustuotemarkkinoita hallitsee yksi merkittävä meijeriteollisuuden yritys. Kehityksen taustalla on myös teollisuuden panostus tuotekehitykseen, mikä näkyy erityisesti terveysvaikutteisten tuotteiden markkinoiden kasvuna.

Kaupan ja ravintolapalveluiden osuus elintarvikeketjun bruttoarvosta on kasvanut selvästi kaikissa tuoteryhmissä. Keskimäärin kaupan ja ravintolapalveluiden bruttomarginaali on kasvanut liki $5 \%$ prosenttia vuodessa; vuonna 2009 kaupan ja ravintolapalveluiden bruttomarginaali oli 8,1 prosenttiyksikköä suurempi kuin vuonna 2000. Selvimmin kaupan ja ravintolapalveluiden bruttomarginaali on kasvanut lihatuotteissa - 10,5 prosenttiyksikköä eli keskimäärin 5,2 \% vuodessa. Tuloksesta voidaan päätellä, että elintarvikkeiden jalostusasteen nousu on hyödyttänyt myös kauppaa ja ravintolapalveluita. Kuten edellä todettiin, pitkälle jalostettujen einesten valmistus sisältyy lihatuoteryhmään. Maitotaloustuotteissa kaupan ja ravintolapalveluiden yhteenlaskettu bruttomarginaali on sen sijaan kasvanut hieman hitaammin kuin elintarvikkeissa keskimäärin. Maitotaloustuotteiden ryhmässä kaupan ja ravintolapalveluiden bruttomarginaali on kasvanut vuosina 
2000-2009 hieman yli $7 \%$, mikä on tarkoittanut 4,5 prosentin keskimääräistä vuotuista nousua. Viljatuotteissa kaupan ja ravintolapalveluiden bruttomarginaali oli vuonna 2009 yli $8 \%$ korkeammalla tasolla kuin vuonna 2000. Keskimäärin kauppa ja ravintolapalvelut ovat siis tässä tuoteryhmässä kasvattaneet osuuttaan liki $4 \%$ vuodessa.

Kuvioista 4 ja 5 nähdään myös tuonnin osuuden voimakas kasvu liha- ja maitotuotteiden kokonaiskulutusmenoista. Lihatuotteissa tuonnin osuus kulutusmenojen bruttoarvosta on kasvanut keskimäärin $2,5 \%$ vuodessa ja maitotaloustuotteissa vastaavasti keskimäärin $3,1 \%$ vuodessa. Vuonna 2009 tuonnilla olikin lihatuotteissa 2,5 prosenttiyksikköä suurempi bruttoarvo-osuus kuin vuonna 2000. Vastaavasti maitotaloustuotteissa tuonnin osuus arvoketjun bruttoarvosta oli 3,6 prosenttiyksikköä suurempi vuonna 2009 kuin vuonna 2000.

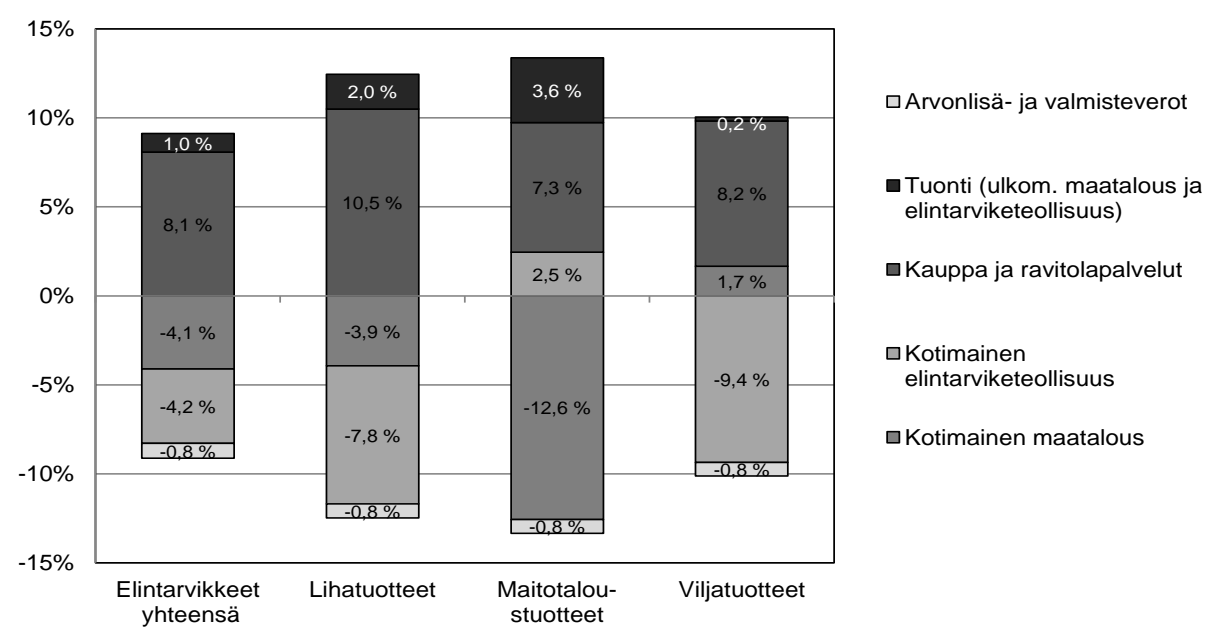

Kuvio 4. Bruttomarginaalien muutos (prosenttiyksikköä) tuoteryhmittäin 2000-2009. Lähteet: Tilastokeskus, Tulli, MTT taloustutkimus, Elintarviketeollisuusliitto, MaRa ry ja kirjoittajien omat laskelmat.

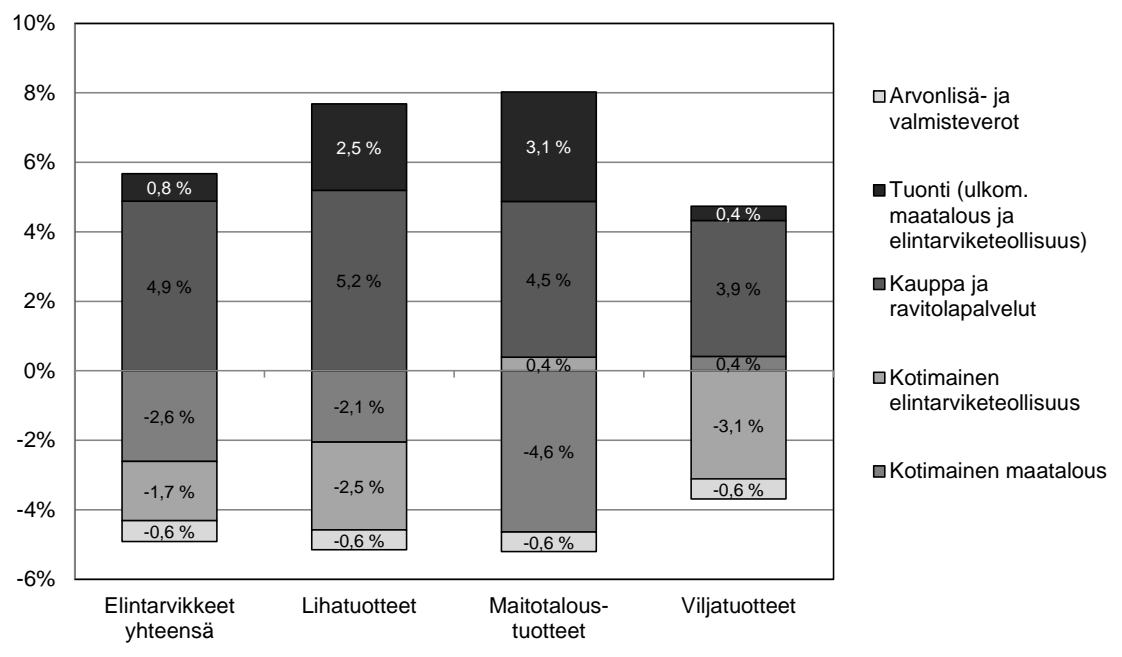

Kuvio 5. Bruttomarginaalien keskimääräinen prosentuaalinen muutos vuodessa (2000-2009). Lähteet:

Tilastokeskus, Tulli, MTT taloustutkimus, Elintarviketeollisuusliitto, MaRa ry ja kirjoittajien omat laskelmat.

\section{Maiden välinen vertailu elintarvikeketjun bruttomarginaalien muodostumiseen}

Tarkastellaan seuraavaksi maiden välisiä eroja bruttomarginaalien muodostumissa elintarvikeketjussa. Vertailuun on valittu kahdeksan maata: Espanja, Italia, Iso-Britannia, Ranska, Ruotsi, Saksa, Tanska, ja USA. Koska monissa maissa eri elintarvikkeisiin sovelletaan erisuuruisia arvonlisäverokantoja sekä joihinkin elintarvikkeisiin kohdistuu lisäksi valmisteveroja, arvonlisä- ja valmisteveroja ei ole pystytty erottamaan kaupan- ja ravintolapalveluiden bruttomarginaalista. Tarkastelussa hyödynnetään edellisen 
luvun bruttomarginaalilaskentaan verrattuna yksinkertaistettua laskentakaavaa. Elintarvikeketjun bruttoarvon muodostuksessa erotetaan maatalouden, elintarviketeollisuuden ja tuonnin osuudet. Näiden vähentämisen jälkeinen osuus elintarvikkeiden ja ravintolapalveluiden kulutuksen bruttoarvosta sisältää kaupan ja ravintolapalveluiden bruttomarginaalin sekä verojen osuuden. Lisäksi on huomioitava, että eläinten ruokia ja alkoholia ei ole pystytty irrottamaan tarkastelusta.

Kuviossa 6 on esitetty elintarvikeketjun bruttomarginaalit tarkastelun kohteena olevissa maissa vuonna 2009. Kuviosta nähdään, että maatalouden osuus ruuan kulutuksen bruttoarvosta on suurin USA:ssa - noin $18 \%$. Myös Tanskassa, Ranskassa ja Italiassa maatalouden osuus ylittää $10 \%$. Vastaavasti Isossa-Britanniassa maatalouden bruttomarginaali jää noin 6 prosenttiin, mikä on tarkasteltavien maiden joukossa alhaisin maatalouden prosenttiosuus.

Elintarviketeollisuuden bruttomarginaalit ovat maiden välillä huomattavan tasasuuruisia - noin $25 \%$. Poikkeuksen tekee Saksa, missä elintarviketeollisuuden bruttomarginaali vuonna 2009 oli $40 \%$. USA:ssa elintarviketeollisuus saa ruuan kulutuksen bruttoarvosta kolmanneksen, eli jonkin verran enemmän kuin tarkasteltavissa maissa keskimäärin.

Tuonnin osuus elintarvikkeiden kokonaiskulutuksesta sen sijaan vaihtelee maiden välillä melko voimakkaasti. Tanskassa ja Ruotsissa tuonnin osuus ylittää $25 \%$. Saksassa tuontiruuan osuus elintarvikkeiden kokonaiskulutusmenoista on noin $20 \%$. Sen sijaan USA:ssa tuonnille menevä osuus jää noin 6 prosenttiin. Myös Espanjassa tuonnin osuus jää verraten alhaiseksi, 10 prosenttiin.

Kaupan ja ravintolapalveluiden bruttomarginaalit sekä verot sisältävä jäännöserä vaihtelee myös voimakkaasti maiden välillä. Havaintoa taustoittavat monet tekijät. Ensinnäkin elintarvikkeisiin kohdistuvissa yleisissä arvonlisäverokannoissa on suuria eroja maiden välillä; Tanskassa elintarvikkeita verotetaan 25 prosentin alv-kannalla, kun vastaavasti Isossa-Britanniassa elintarvikkeiden yleinen arvonlisäverokanta on nolla. Tanskan verrattain alhaista kaupan, ravintolapalveluiden ja verojen osuutta selittää korkea tuonnin osuus: elintarviketuonnista suurin osa menee suoraan kauppojen hyllyille. Toiseksi ravintolapalveluiden osuus ruuan kokonaiskulutuksessa vaihtelee merkittävästi maiden välillä. Espanjassa, Italiassa ja Isossa-Britanniassa ravintolasyömisen ja -juomisen osuus on noin 50 \%, kun se muissa maissa on 25-30\%. Ravintolapalveluiden suuri osuus elintarvikkeiden kokonaiskulutuksen bruttoarvon muodostumisessa onkin merkittävä selittäjä kaupan, ravintolapalveluiden ja verojen verrattain korkealle osuudelle Italiassa ja Espanjassa. Tarkasteltavista maista korkein kaupan, ravintolapalveluiden ja verojen yhteenlaskettu osuus on Espanjassa 56,5 \% ja alhaisin Saksassa 32,5 \%.

Tarkastellaan seuraavaksi bruttomarginaalien kehitystä 2000-luvulla. Vastaavalla tavalla kuin edellisen luvun tuoteryhmittäisessä tarkastelussa kuviossa 7 on esitetty maittain bruttomarginaalien muutokset elintarvikeketjussa vuodesta 2000 vuoteen 2009. Lisäksi kuviossa 8 on esitetty keskimääräiset prosentuaaliset bruttomarginaalien vuosimuutokset laskettuna vuosilta 2000-2009.

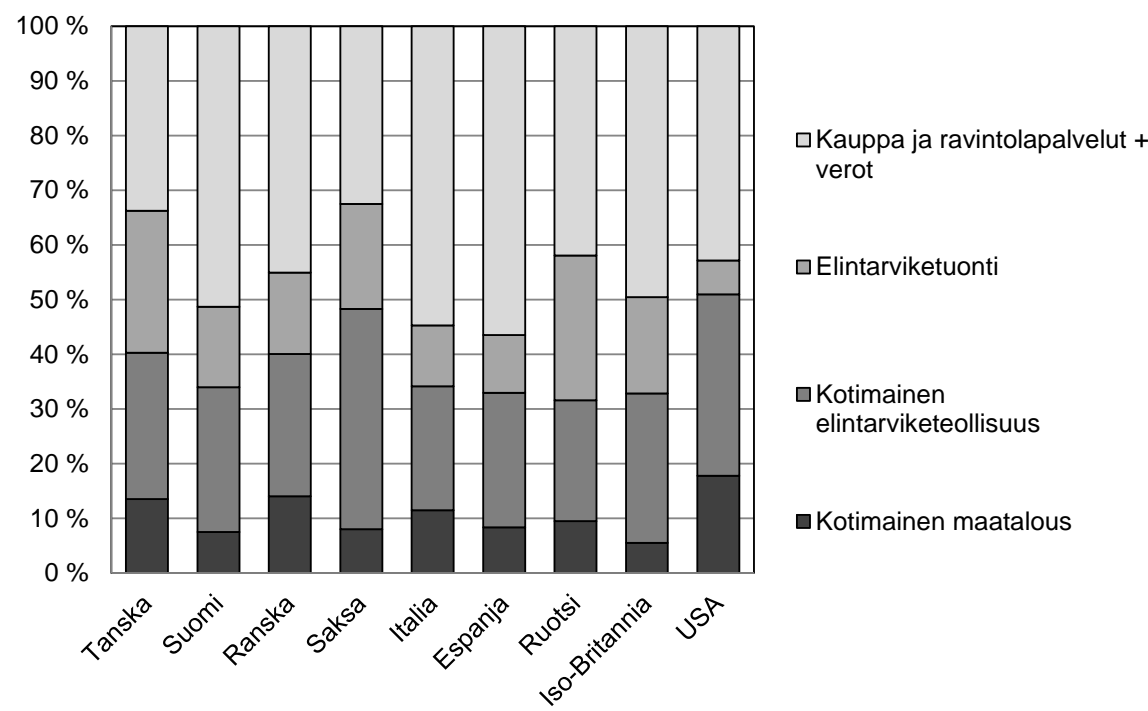

Kuvio 6. Elintarvikkeiden bruttomarginaalit 2009 - maiden välinen vertailu. Lähteet: Eurostat, USDA, OECD, COMTRADE 
Kuvioiden mukaan suurimmat muutokset elintarvikeketjun eri sektorien bruttomarginaaleissa ovat tapahtuneet Pohjoismaissa sekä Ranskassa. Näissä maissa kaupan, ravintolapalveluiden ja verojen yhteenlaskettu osuus ruuan kulutuksen bruttoarvosta on kasvanut kymmenessä vuodessa yli 10 prosenttiyksikköä. Tämä on tarkoittanut 3-5\% keskimääräistä vuotuista kasvua. Vastaavasti maatalouden ja elintarviketeollisuuden bruttomarginaalit ovat pienentyneet kyseisissä maissa 2000luvulla selvästi.

USA:ta lukuun ottamatta maataloudelle menevä osuus elintarvikeketjun bruttoarvosta on pienentynyt tarkastelun kohteena olevissa maissa vuosina 2000-2009. Yleisesti maatalouden bruttomarginaali on laskenut vuodessa keskimäärin 3-5 \% (kuvio 8). Suurimmat maatalouden osuuden pienentymiset ovat kuvioiden 7 ja 8 mukaan nähty Espanjassa Italiassa, Ranskassa ja Ruotsissa.

Pohjoismaissa sekä Ranskassa elintarviketeollisuuden bruttomarginaali on laskenut huomattavasti: Suomessa ja Ruotsissa elintarviketeollisuuden bruttomarginaali on pudonnut yli 10 prosenttiyksikköä, mikä on tarkoittanut 4-5 \% keskimääräistä vuotuista bruttomarginaalin laskua vuosina 2000-2009. Saksassa, Espanjassa ja USA:ssa elintarvikekeollisuuden bruttomarginaali on sen sijaan 2000-luvulla noussut.

Tuontielintarvikkeiden osuus ruuan kokonaiskulutuksesta on kasvanut kaikissa tarkasteltavissa maissa. Keskimäärin tuonnin osuus on tarkasteltavissa maissa kasvanut 1-4 \% vuodessa.

Kuvioista 7 ja 8 nähdään vielä, että kaupan, ravintolapalveluiden ja verojen osuus on pienentynyt USA:ssa ja pysynyt Saksassa sekä Isossa-Britanniassa samalla tasolla vuosina 2000-2009. Näissä maissa bruttomarginaalien kokonaismuutokset ovat kaiken kaikkiaan pysyneet 2000-luvulla suhteellisen pieninä, alle 5 prosenttiyksikössä.

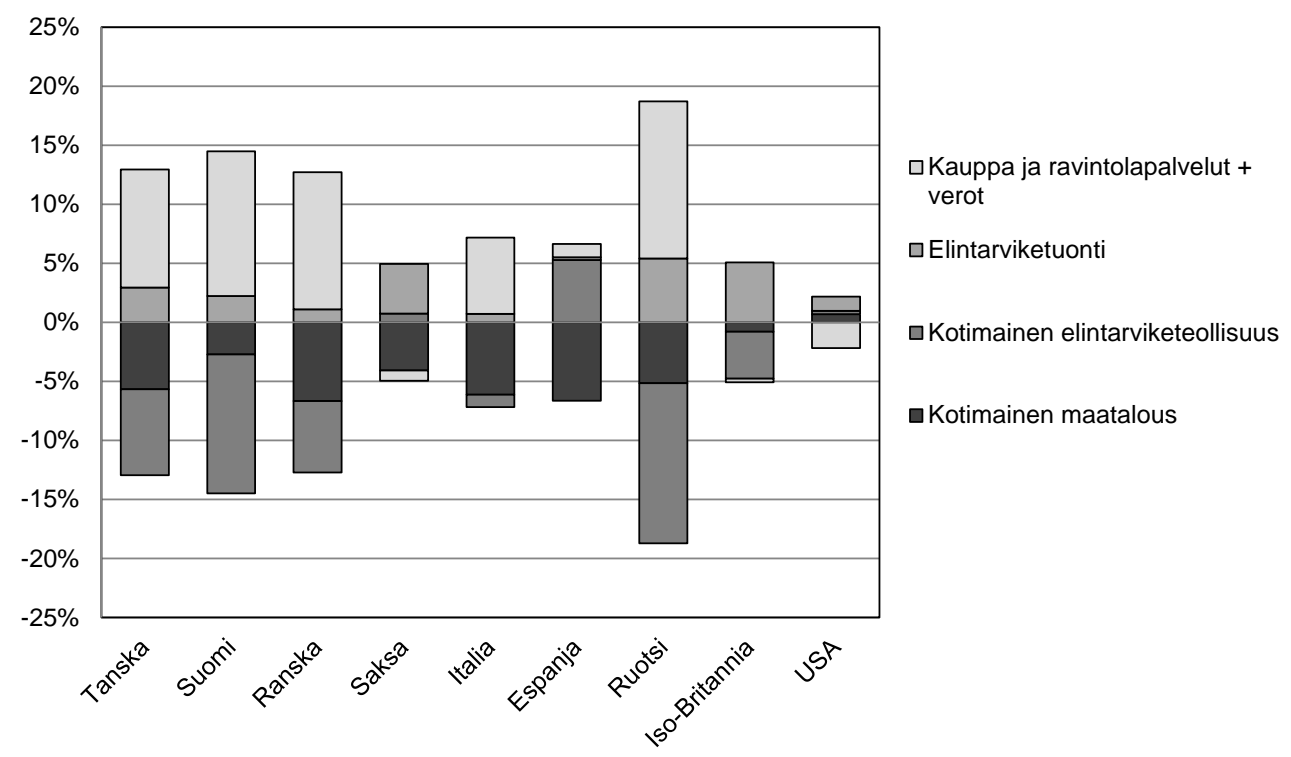

Kuvio 7. Bruttomarginaalien muutos vertailumaissa 2000-2009. Lähteet: Eurostat, USDA, OECD, COMTRADE 


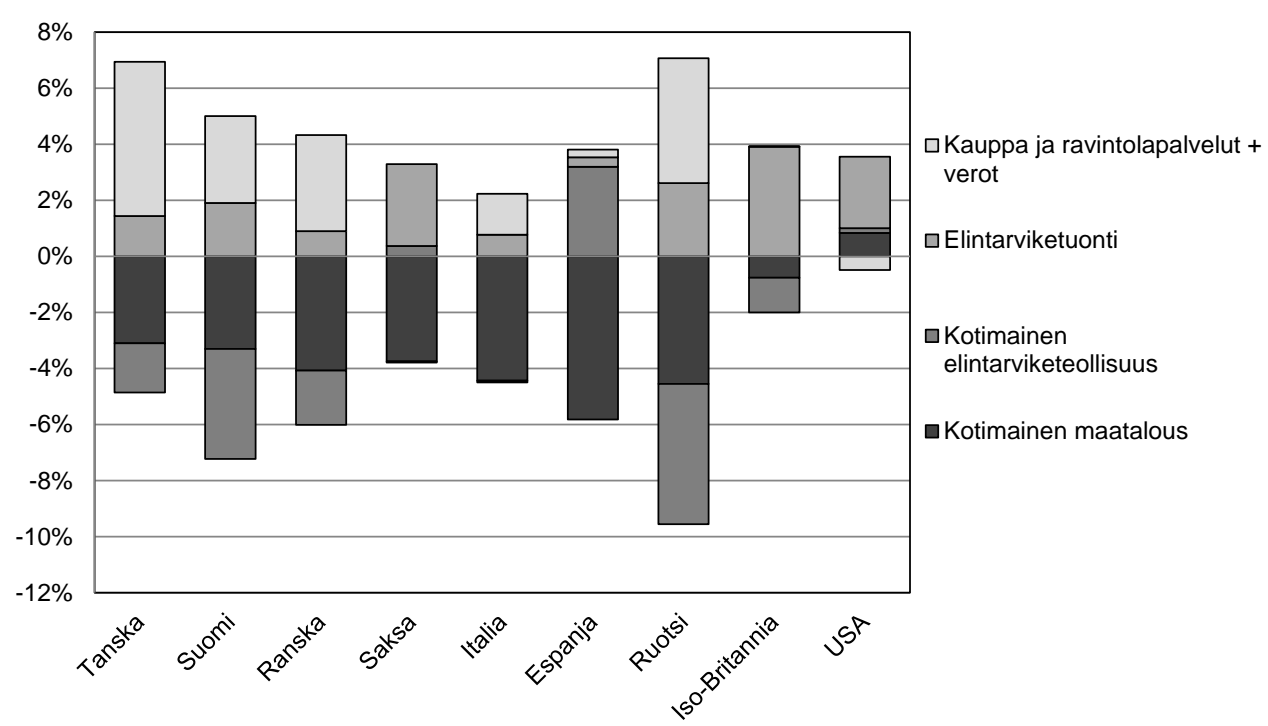

Kuvio 8. Bruttomarginaalien keskimääräinen prosentuaalinen muutos vertailumaissa vuodessa (2000-2009). Lähteet: Eurostat, USDA, OECD, COMTRADE

\section{Johtopäätökset}

Suomen elintarvikemarkkinat ovat voimakkaasti integroituneet kansainvälisiin elintarvikemarkkinoihin. Maailmanmarkkinoilla tapahtuvat muutokset heijastuvat välittömästi kotimarkkinoille. Suomalaiset elintarvikeyritykset ovat kansainvälistyneet ja tuonnin suhteellinen merkitys kotimaisessa kulutuksessa on koko ajan kasvussa. Markkinoiden kilpailu ei kuitenkaan ole ulottunut kauppaan asti. Kaupan keskittyminen on jatkunut voimakkaana. Muuttunut markkinarakenne näkyy bruttomarginaalien kehityksessä vuosina 2000-2009.

Maatalouden bruttomarginaalit ovat vuotta 2008 lukuun ottamatta pienentyneet koko tarkastelujakson ajan. Myös elintarviketeollisuuden bruttomarginaalit ovat 2000-luvalla kokonaisuudessaan pienentyneet. Vuosikymmenen loppupuolella elintarviketeollisuus on kuitenkin pystynyt hieman parantamaan asemiaan koko ketjussa. Samaan aikaan kaupan ja ravintolapalveluiden bruttomarginaalit ovat kasvaneet selvästi kaikissa tuoteryhmissä. Kaupan marginaalin kasvu oli nopeinta 2000-luvun alkuvuosina.

Kotimaisen maatalouden bruttomarginaalin pienentymistä selittää ennen kaikkea elintarvikkeiden jalostusasteen kasvu. Tuotteen jalostusasteen kasvaessa maatalousraaka-aineen suhteellinen osuus lopputuotteen hinnasta pienenee. Samaan aikaan elintarviketuonti on kasvanut voimakkaasti ja syönyt kotimaisen maatalouden osuutta elintarvikeketjussa. Elintarviketeollisuudelle tuonnin vaikutus on ollut kaksisuuntainen. Kotimaisen raaka-ainetarjonnan lisäksi elintarviketeollisuudella on ollut aikaisempaa paremmat mahdollisuudet ulkomaisen raaka-aineen käyttöön kotimaisen rinnalla. Myös elintarvikkeiden vientimahdollisuudet ovat lisääntyneet.

Toisaalta jalostettujen elintarvikkeiden tuonti on lisännyt kotimaisen elintarviketeollisuuden kohtaamaa kilpailua selvästi. Kauppa on pystynyt kilpailuttamaan kotimaiset elintarvikeyritykset paitsi toisiaan myös tuontituotteita vastaan. Tämä on vahvistanut kaupan asemaa.

Bruttomarginaalien vertailu yhdeksän eri maan välillä kertoo, että elintarvikemarkkinoiden kehitys kaikissa maissa on samansuuntaista. Suurimmat muutokset elintarvikeketjun eri sektorien bruttomarginaaleissa ovat tapahtuneet Pohjoismaissa sekä Ranskassa. Näissä maissa kaupan, ravintolapalveluiden ja verojen yhteenlaskettu osuus ruuan kulutuksen bruttoarvosta on kasvanut kymmenessä vuodessa selvästi. Vastaavasti maatalouden ja elintarviketeollisuuden bruttomarginaalit ovat pienentyneet.

Bruttomarginaalit ja niiden kehitys antavat hyvän kuvan elintarvikemarkkinoiden rakenteesta Suomessa. Marginaaleissa tapahtuneet muutokset heijastavat myös elintarvikeketjussa tapahtunutta merkittävää rakenteellista muutosta. Laskelmien avulla ei kuitenkaan voida sanoa, kuinka merkittävä osa marginaalin suhteissa tapahtuneista muutoksista on seurausta eroista tuottavuuden kasvussa ketjun eri osissa. Lisäksi entisestään korostunut logistiikan ja kuljetuskustannusten merkitys jää analyysin ulkopuolelle. 


\section{Lähteet}

Digby, M. 1989. Marketing Margins in the Meat Sector, England and Wales 1978-1988. Journal of Agricultural Economics 40: 129-142.

Euroopan komissio 2009. A Better Functioning Food Supply Chain in Europe. Communication from the Commission to the European Parliament, the Council, the European Economic and Social Committee and the Committee of the Regions. Brussels 28.10.2009, COM (2009) 591.

Huovari, J. ja Jalava, J. 2007. Kansainvälinen ja vertaileva näkökulma Suomen tuottavuuskehitykseen. Pellervon taloudellinen tutkimuslaitos PTT. Työpapereita 96.

Jalonoja, K. ja Pietola, K. 2004. Spatial integration between Finnish and Dutch potato markets. Acta agriculturae Scandinavica. Section C Food economics 11: 12-20.

Kinsey, J. ja Senauer, B.1996. Consumer Trends and Changing Food Retailing Formats. American Journal of Agricultural Economics 78: 1187-1191.

Kotilainen, M., Koski, H., Mankinen, R. ja Rantala, O. 2010. Elintarvikkeiden hinnanmuodostus ja markkinoiden toimivuus. Elinkeinoelämän tutkimuslaitos ETLA. Keskustelualoitteita No. 1209.

Kuosmanen, T., Niemi, J. ja Sipiläinen, T. 2009. Maataloustuen ja tuottavuuden vaikutukset elintarvikkeiden hintamarginaaleihin ja hinnanmuodostukseen. MTT Kasvu3. Maa- ja elintarviketalouden tutkimuskeskus.

Løyland, J., Pettersen, I., Selte, H., Becken, L-E. ja Flaten, O. 2001. Kjøttpriser fra bonde til butikk [Development of gross margins for pork and beef products from 1998 to 2001. Norwegian Agricultural Economics Research Institute Report 2001-10.

McCorriston, S. 2002. Why should imperfect competition matter to agricultural economists? European Review of Agricultural Economics 29(3): 349-372.

Schroeter, J. R., Azzam, A. M. ja Zhang, M. 2000. Measuring Market Power in Bilateral Oligopoly: The Wholesale Market for Beef. Southern Economic Journal 66(3): 526-547.

\section{Tilastolähteet}

AC Nielsen. Vähittäiskaupan markkinaosuudet Suomessa.

Elintarviketeollisuusliitto www.etl.fi

Eurostat http://epp.eurostat.ec.europa.eu

Kaupan liitto. Vähittäiskaupan markkinaosuudet Suomessa.

MaRa ry www.mara.fi

MTT Taloustutkimus, maatalouden kokonaislaskelma www.mtt.fi

OECD www.oecd.org

Tilastokeskus www.stat.fi

Tulli, ulkomaankauppatilastot http://uljas.tulli.fi

USDA Economic Research Service www.ers.usda.gov

UN Comtrade http://comtrade.un.org

Veronmaksajain keskusliitto www.veronmaksajat.fi 